\title{
Unusual Mortality Events of Harbor Porpoise Strandings in North Carolina, 1997-2009
}

\author{
Aleta A. Hohn, ${ }^{1}$ David S. Rotstein, ${ }^{2}$ and Barbie L. Byrd ${ }^{1}$ \\ ${ }^{1}$ NOAA, National Marine Fisheries Service, Southeast Fisheries Science Center, NOAA Beaufort Laboratory, 101 Pivers Island Road, \\ Beaufort, NC 28516, USA \\ ${ }^{2}$ Marine Mammal Pathology Services, 19117 Bloomfield Road, Olney, MD 20832, USA
}

Correspondence should be addressed to Aleta A. Hohn; aleta.hohn@noaa.gov

Received 22 April 2013; Accepted 16 July 2013

Academic Editor: Nobuyuki Miyazaki

Copyright (C) 2013 Aleta A. Hohn et al. This is an open access article distributed under the Creative Commons Attribution License, which permits unrestricted use, distribution, and reproduction in any medium, provided the original work is properly cited.

A marked increase in the frequency of harbor porpoises (Phocoena phocoena) stranded in North Carolina in 2005 was declared as an Unusual Mortality Event (UME). Strandings occurred in January through May when harbor porpoises are seasonally present. Increased stranding rates were measured relative to a threshold to determine that the UME was occurring. The threshold analysis also revealed elevated strandings during 1999, an undeclared UME year. Recovered carcasses during 1999 and 2005 accounted for 39\% of 261 strandings during 1997-2009. During 2005, of 43 strandings, primary or secondary causes of mortality included fishery interactions, emaciation, and interspecific aggression. Apart from small but significant differences in timing and condition of strandings, composition of strandings during UME and non-UME years was similar, with most being young-of-the-year and occurring during March and April, north of Cape Hatteras. Porpoises had high levels of parasitic infestation typical for this species. However, no indication of infectious disease and no cause of the 2005 event were found from gross and histologic findings. Response to UMEs is challenging, particularly along the expanses of North Carolina beaches, requiring additional effort to obtain carcasses in sufficiently fresh condition to determine the cause of these events.

\section{Introduction}

Of the six species in the odontocete family Phocoenidae, only one is found in the Atlantic Ocean, the harbor porpoise (Phocoena phocoena). Members of this family, including the harbor porpoise, generally occur at high latitude, while harbor porpoises are found only in the northern hemisphere [1]. Although it is primarily a cold-water temperate and boreal species, documented takes in gillnet fisheries in the western mid-Atlantic region in winter [2] support the mid-Atlantic coast of the United States of America (USA) being part of the normal winter range for the species. Further, harbor porpoises are one of the most commonly stranded species along the extensive beaches of North Carolina (NC) [3]. Historical data indicate that along the US Atlantic coast only Massachusetts has more documented strandings than NC [4].

Worldwide, harbor porpoise strandings have been associated with infectious and noninfectious diseases. Infectious diseases include morbillivirus (e.g., [5, 6]), herpesvirus [5], brucellosis [7, 8], bartonellosis $[9,10]$, and verminous pneumonia $[6,11,12]$. Papillomavirus has been reported to result in self-limiting cutaneous lesions rather than mortalities [1315]. Noninfectious diseases found in harbor porpoises include colloid goiter [16] and dystocia [17]. Domoic acid toxicosis was identified in harbor porpoises from California [18]. From detailed postmortem examinations of 41 stranded harbor porpoises from the United Kingdom (UK), parasitic and bacterial pneumonia were common causes of death and nonfatal parasitic infestation was common [17]. Jepson et al. [19] found a correlation between body burdens of polychlorinated biphenyls (PCBs) and health status of harbor porpoises in the United Kingdom; animals with infectious diseases had higher body burdens of PCBs.

Harbor porpoise mortalities also occur as a result of nondisease factors. Fishery interactions have been widely documented (e.g., [17, 20-24], including along the Atlantic coast of the USA. For example, fishery interactions in gillnets have been observed by at-sea observers from the Gulf of Maine to 
the mid-Atlantic [2] as well as determined from the presence of entanglement lesions on stranded harbor porpoises along the coasts of Maryland, Virginia, and NC since at least the mid-1990s [25]. During 1997-2008 in NC, Byrd et al. [3] documented that about $21 \%$ of stranded porpoises for which it was possible to document whether a human interaction occurred ( $n=52)$ showed entanglement lesions consistent with fishing gear. Another $13 \%$ were mutilated in a manner consistent with mutilation seen on carcasses with entanglement lesions $[26,27]$; although the former were too decomposed to determine if entanglement lesions were present, the type of mutilation infers that they also died due to fishery interactions. Apart from human interactions, harbor porpoises are also susceptible to interactions with dolphins. Blunt-force trauma likely due to aggressive interactions with bottlenose dolphins (Tursiops truncatus) was identified as the most common identified cause of death in a multiyear sample of harbor porpoise strandings from California [18]. The findings were supported by direct observations of aggressive behaviors of bottlenose dolphins toward harbor porpoises in California [28]. Harassment by Pacific white-sided dolphins (Lagenorhynchus obliquidens) of a neonatal harbor porpoise also was observed in Puget Sound, Washington, and this porpoise ultimately died [29]. Furthermore, in a study of 106 stranded harbor porpoises in the UK, the majority had internal and external traumatic injuries attributed to aggressive interactions between the porpoises and bottlenose dolphins [30]. The authors suggested that dolphin-induced porpoise mortality might result in a significant overall source of mortality for harbor porpoises in that area.

While winter strandings in NC are common, the number of strandings per year is highly variable. In March 2005, so many harbor porpoises were stranding that, at times, responders needed to continuously drive beaches any given day, intermittently loading carcasses into the truck instead of responding to strandings individually. By late March, the number of reported strandings was sufficiently high that it triggered a request to the Working Group on Marine Mammal Unusual Mortality Events (WGMMUME) on 30 March 2005, that the strandings be designated as an Unusual Mortality Event (UME) (MMPA 16 U.S.C. 1361 et seq.) [31, 32] (http://www.nmfs.noaa.gov/pr/health/mmume/criteria .htm). The purpose of this study was to (1) evaluate the strandings in 2005 relative to other years in order to characterize the UME and (2) describe gross and histologic findings from carcasses that stranded during the 2005 event.

\section{Materials and Methods}

2.1. Stranding Response and Data Collection. Members of the stranding network collected basic, or Level A, data (e.g., species, geographic coordinates, straight length, and sex; [33]) whenever possible for each harbor porpoise recovered in NC (Figure 1). Level A data also include a condition code characterizing the stage of decomposition: (1) live animal, (2) carcass - fresh dead, (3) carcass-moderate decomposition, (4) carcass-advanced decomposition, (5) carcassmummified or skeletal remains, or (6) dead but unknown because carcass was not recovered. Additionally, strandings were examined for signs of human interaction (HI) [27], particularly for indications of fishery interactions (HI-FI) [34]. Each carcass was assigned to a HI category: positive for fishery interactions (HI-FI), positive for human interactions not attributable to fisheries (HI-Other), negative for human interactions (HI-No), or could not be determined if a human interaction occurred (HI-CBD) [34]. Carcasses were also examined for signs of interspecific aggression, such as rake marks [30]. For this study, stranding data were extracted for the period 1997-2009; relatively consistent coast-wide coverage by the stranding network began in 1997 [3], providing reliable data in comparison to other years, and the last complete year for harbor porpoise data in the NC database was 2009.

2.2. Determination of the 1999 and 2005 Events as UMEs. The applicable UME criterion for the declaration of this event was "a marked increase in the magnitude...[of] strandings when compared to prior records" (http://www.nmfs.noaa.gov/pr/ health/mmume/criteria.htm). Thus, stranding rates of harbor porpoises during 2005 were compared to historical average strandings starting from 1997. Data from 1999 were excluded from the historical average because of an extraordinarily high number of strandings of harbor porpoises that year. These strandings likely represented an undeclared UME, in part because the complete "historical" record at that time encompassed only the prior two years.

Marked increases in the magnitude of strandings were defined as stranding frequencies that exceeded the historical overall mean plus two standard deviations (SDs) [31], in this case by week. The weekly mean plus two SDs is hereafter referred to as the weekly UME threshold. Weeks consisted of 7 -day increments by Julian date starting on 1 January. The number of strandings per week in 2005 was compared to the historical UME threshold for that week calculated from data from 1997-2004 (excluding 1999, as noted above). This indicator is referred to as UME threshold A. To determine whether the 2005 event would have been a UME if a longer time series of stranding data were available, an a posteriori threshold analysis was conducted that also included stranding data from 2006-2009 (the longer time series is hereafter referred to as UME threshold B). To determine if a UME declaration for 1999 would have been warranted, similar comparisons were made between data from 1999 and UME thresholds A and B. The focus for the weekly monitoring was on detecting elevated stranding rates in short periods of time during the event. To evaluate whether strandings were elevated when retrospectively summed by year, annual strandings during 2005 and 1999 were compared to the annual mean plus 2 SDs using years in a manner comparable to weekly thresholds A and B.

\subsection{Characteristics of Harbor Porpoises Stranded in North Car-} olina. Contingency table analysis was used to test for effects of month, condition, sex ratio, age-class, and HI category on the relative frequency of strandings that occurred during the declared (2005) and undeclared (1999) UME and non-UME years. For temporal effects, calendar month was used instead of week due to the excessive number of zeros and small values 


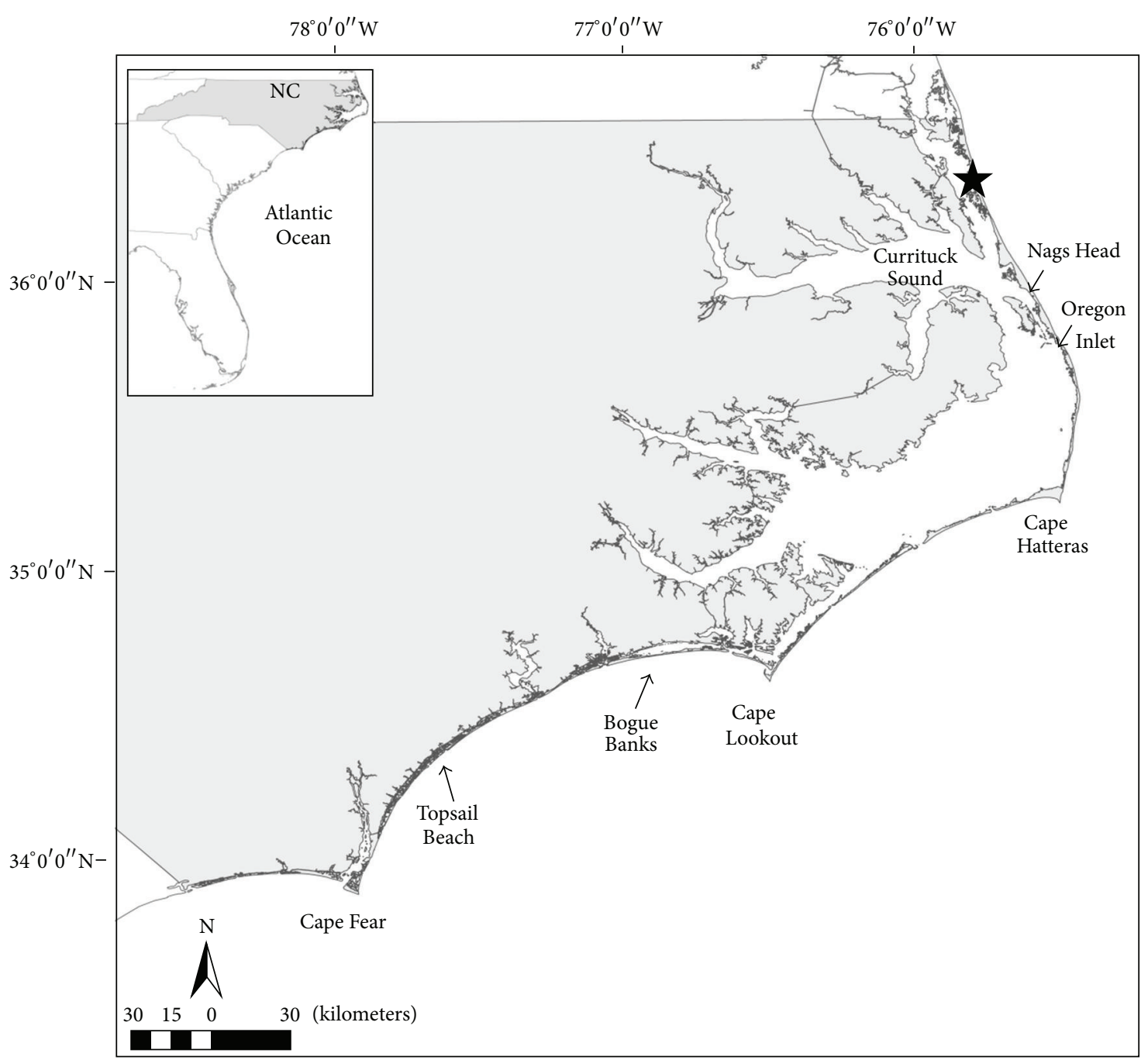

Figure 1: Coastal North Carolina. The barrier islands east of the island Bogue Banks north to the Virginia border are called the Outer Banks. The star corresponds to the end of Highway 12, after which access to the area to the north is by beach only.

in the weekly time series. Analyses of condition excluded Code 6 carcasses because their condition and disposition were unknown. When both sex and length were recorded, strandings were assigned to age-class categories: (1) youngof-year (YOY) $\leq 118 \mathrm{~cm}$ [35], (2) juvenile $=119-134 \mathrm{~cm}$ for males [35] and 119-142 cm for females [36], and (3) mature $>135 \mathrm{~cm}$ for males and $>142 \mathrm{~cm}$ for females. Because of sexual dimorphism in mature porpoises, carcasses not identified to sex were excluded if lengths were $119-142 \mathrm{~cm}$; that is, all animals $<119 \mathrm{~cm}$ were considered YOYs, and all animals of either sex $>142 \mathrm{~cm}$ were considered mature. Independence in parameters between UME and non-UME years was tested using Fisher's exact tests due to small sample sizes in some cells and the skewed distribution of observations, for example, few strandings occurred in the first or last months of the timeframe when strandings typically occur. When significant $P$ values $(P \leq 0.05)$ indicated lack of fit, standardized residuals $(>|1.96|)$ from Chi-Square tests were used to identify in which cells significant differences occurred. All tests were conducted using SAS versus 9.3 (SAS Institute, 100 SAS Campus Drive, Cary, NC 27513-2414).
2.4. Pathology Investigation of 2005 Strandings. During the 2005 UME, intact carcasses were necropsied immediately or, if time did not allow for immediate necropsy, frozen for future necropsy. When possible, histological samples were collected from euthanized animals and Code 2 carcasses that had not been frozen; samples collected from major organs (heart, lung, liver, kidney, spleen, liver, lymph nodes, and brain) and lesions were preserved in $10 \%$ formalin. Preserved subsamples were embedded in tissue cassettes, sectioned at 5 to $7 \mu$, and stained with hematoxylin and eosin. Special stains, Periodic acid-Schiff (PAS) and Gomori-Grocott methenamine silver (GMS) for fungi and algae, were used as needed. All slides were examined by a single pathologist, DSR. Limited necropsies were conducted on carcasses in poor condition. Only external examination for gross observations, such as emaciation, mutilation, or scavenger damage, was possible for other carcasses. Contingency table analysis with Fisher's exact test was used to test for differences in relative frequency of emaciated animals between the declared (2005) and undeclared (1999) UME and the non-UME years. 


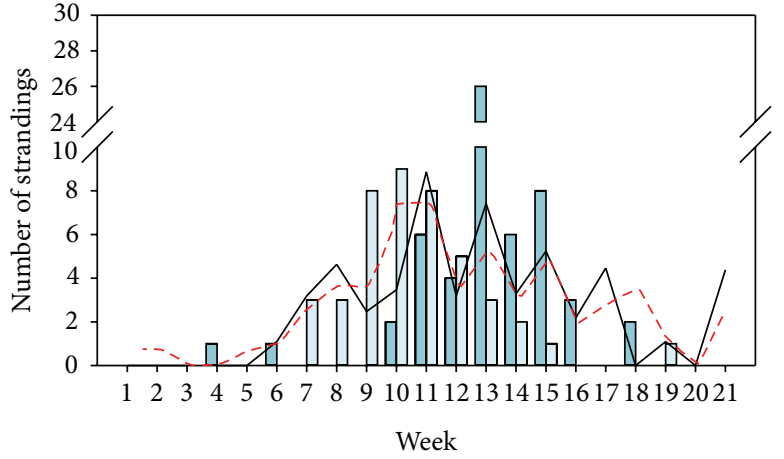

(a)

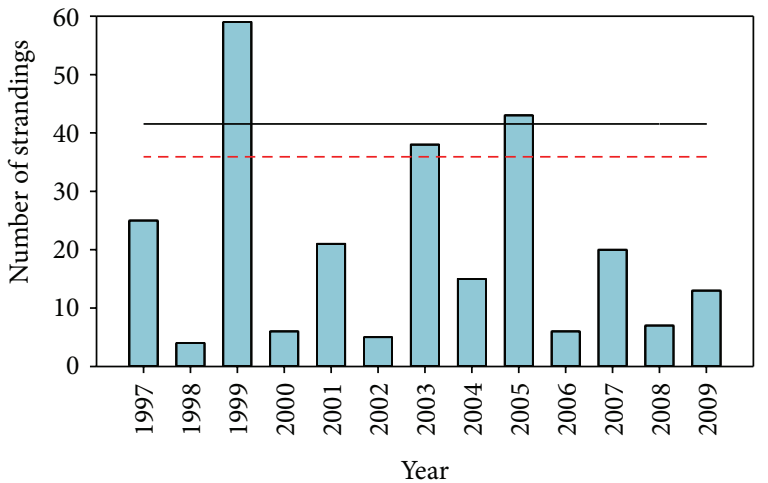

(b)

Figure 2: (a) Weekly harbor porpoise strandings in 1999 (darker blue bars) and 2005 (lighter blue bars) compared to weekly threshold A (mean + 2 standard deviations: 1997-1998, 2000-2004) (black horizontal solid line) and threshold B (mean + 2 standard deviations: 19971998, 2000-2004, 2006-2009) (red horizontal dashed line). (b) Annual harbor porpoise strandings during 1997-2009 (blue bars) compared to annual threshold A (black horizontal solid line) and threshold B (red horizontal dashed line).

\section{Results}

3.1. Determination of the 1999 and 2005 Events as UMEs. From 1997 to 2009, 262 harbor porpoise strandings were reported, ranging annually from 4 (1998) to 59 (1999), with an overall annual mean of $20.1(\mathrm{SD}=17.15)$ and a mean of 14.5 $(\mathrm{SD}=10.7)$ when 2005 and 1999 were excluded. Thirty-nine percent of the strandings occurred during 1999 and 2005. On a weekly basis, elevated strandings occurred during both 2005 (declared UME) and 1999 (undeclared UME). The weekly stranding frequency in 2005 exceeded the corresponding weekly threshold A from week 9 (26 February-4 March) through week 12 (19-25 March) (Figure 2). These data were used to make the initial declaration of a UME. In the $a$ posteriori analysis, the same weeks exceeded threshold B with the addition of week seven (Figure 2). The weekly stranding frequency in 1999 exceeded the corresponding weekly thresholds A and B in weeks 12-16 (Figure 2). Thresholds were also exceeded in weeks 4 and 6 reflecting only one stranding when the mean number of strandings was close to zero (Figure 2). Week 13 in 1999 had more porpoise strandings than the annual total in all but three years: 1999, 2003, and 2005. Retrospectively, the annual stranding frequency exceeded the annual thresholds A and B during both 2005 and 1999, while 2003 exceeded threshold B (Figure 2).

\subsection{Characteristics of Harbor Porpoises Stranded in North} Carolina. Overall, harbor porpoises stranded between January and May, but primarily in February through April (Figure 3). Relative to non-UME years, in 2005, more strandings occurred in March and fewer occurred in April $(P=$ 0.03), while in 1999, in addition to the notable peak in March (Figure 3), fewer strandings occurred in February $(P=$ 0.001 ) (Figure 3 ). These opposite patterns of earlier versus later strandings were emphasized when comparing 2005 to $1999(P=0.0007)$.

During non-UME years, harbor porpoises were recovered from the NC border with Virginia to Topsail Beach ( $\sim 10 \mathrm{~km}$ of coastline) (Figure 4 ); 84\% of strandings occurred north of Cape Hatteras ( $160 \mathrm{~km}$ of coastline). The spatial patterns were similar in 2005 (77\% north of Cape Hatteras) and 1999 (88\% north of Cape Hatteras), although in 2005 most of the strandings occurred in the northern half of the coast between the Virginia Line and Cape Hatteras, and in 1999 most strandings were in the southern half. Strandings inshore were rare, occurring only twice and both in 2005.

Biological characteristics during non-UME and UME years were similar. Sex could be determined for $78 \%$ of stranded harbor porpoises between 1997 and 2009, with almost equal numbers of females and males (105 females, 99 males). The sex ratio did not differ between non-UME years and 2005 or $1999(P=0.26$ and $P=1.00$, resp.), or between 2005 and $1999(P=1.00)$. For both sexes, stranded porpoises ranged from 84 to $169 \mathrm{~cm}$ in total length $(n=99$, actual length, not estimated) during non-UME years, from 99 to $154 \mathrm{~cm}$ in $2005(n=31)$, and from 107 to $143 \mathrm{~cm}$ in $1999(n=$ 39). The relative age structure (YOY, juvenile, and adult) did not differ between non-UME years and 2005 (females, $P=$ 0.26 ; males, $P=0.41$ ) or 1999 (females $P=0.48$; males $P=$ 0.18 ) or between 2005 and 1999 (females, $P=0.74$, males, $P=0.41)$. The most prevalent age class in all years and for both sexes was YOY (72\%) (Figure 5); none of the few mature animals stranded during the study period was recovered in 1999 (Figure 5), and only one was documented in 2005. Only two harbor porpoises were pregnant, one in March 2001 with a $54 \mathrm{~cm}$ fetus and the other in January 2006 with a $40 \mathrm{~cm}$ fetus. Neither pregnant female was lactating. An additional 26 animals were measured (size range $89-136 \mathrm{~cm}$ ), but sex could not be determined. Although it was not possible to categorize the single animal $>136 \mathrm{~cm}$ as adult (if it was male) or juvenile (if it was female), 20 of the strandings CBD for sex were YOYs $(\leq 118 \mathrm{~cm})$.

Condition code was recorded for all 43 specimens in 2005. The majority of strandings were condition code 3 (51\%) (Figure 3). There was no evidence of differences in condition between non-UME years (mean condition code $=$ $2.73, \mathrm{SD}=0.96)$ and $2005($ mean $=2.72, \mathrm{SD}=0.91)(P=$ 0.35 ), but carcasses in 1999 were relatively more decomposed 
TABLE 1: Information for harbor porpoise strandings during 1997-2009 categorized as positive for human interactions (HI), either HI-FI (fishery interaction) or HI-Other (other evidence of HI). CBD: could not be determined.

\begin{tabular}{|c|c|c|c|c|c|c|c|c|c|c|c|}
\hline HI-category & Field number & Mo & Year & $\begin{array}{l}\text { Condition } \\
\text { code }\end{array}$ & Sex & $\begin{array}{l}\text { Length } \\
(\mathrm{cm})\end{array}$ & Mutilation & $\begin{array}{l}\text { Body } \\
\text { slit }\end{array}$ & $\begin{array}{c}\text { Missing } \\
\text { appendages }\end{array}$ & $\begin{array}{l}\text { Scavenger } \\
\text { damage }\end{array}$ & $\begin{array}{c}\text { Entanglement } \\
\text { lesion } \\
\text { location }\end{array}$ \\
\hline HI-FI & BRM001 & 3 & 1999 & 3 & Female & 132 & No & No & No & Yes & Flukes \\
\hline HI-FI & PTM041 & 3 & 1999 & 3 & Female & - & CBD & No & No & Yes & $\begin{array}{l}\text { Head, left } \\
\text { flipper }\end{array}$ \\
\hline HI-FI & HOF013 & 4 & 1999 & 3 & Male & 121 & Yes & Yes & Yes & Yes & Peduncle \\
\hline HI-FI & KMS099 & 2 & 2001 & 2 & Male & 117 & No & No & No & Yes & Left fluke \\
\hline HI-FI & KMS238 & 2 & 2003 & 2 & Female & 128 & $\mathrm{CBD}$ & No & No & Yes & $\begin{array}{l}\text { Right flipper, } \\
\text { right fluke }\end{array}$ \\
\hline HI-FI & CALO0408 & 4 & 2004 & 3 & Female & 112 & $\mathrm{~N} / \mathrm{R}$ & No & No & $\mathrm{N} / \mathrm{R}$ & Peduncle \\
\hline HI-FI & KMS335 & 4 & 2004 & 2 & Female & 111 & No & No & No & Yes & Right fluke \\
\hline HI-FI & KMS336 & 4 & 2004 & 2 & Female & 115 & No & No & No & Yes & Right fluke \\
\hline HI-FI & KMS388 & 2 & 2005 & 3 & CBD & 108 & No & No & No & Yes & Left flipper \\
\hline HI-FI & KMS404 & 3 & 2005 & 2 & Male & 116 & No & No & No & Yes & $\begin{array}{l}\text { Head, both } \\
\text { flippers }\end{array}$ \\
\hline HI-FI & KMS417 & 4 & 2005 & 2 & Female & - & No & No & No & No & Flipper \\
\hline HI-Other & HOF011 & 3 & 1999 & 3 & Female & - & Yes & Yes & Yes & Yes & N/A \\
\hline HI-Other & JGM001 & 4 & 1999 & 3 & Female & 120 & Yes & No & Yes & Yes & N/A \\
\hline HI-Other & KMS121 & 4 & 2001 & 4 & CBD & - & Yes & No & Yes & Yes & N/A \\
\hline HI-Other & СМТ001 & 4 & 2003 & 3 & Female & - & Yes & No & Yes & Yes & N/A \\
\hline HI-Other & СMT002 & 4 & 2003 & 3 & Female & - & Yes & No & Yes & Yes & N/A \\
\hline HI-Other & СMT004 & 4 & 2003 & 3 & Male & 105 & Yes & No & Yes & Yes & N/A \\
\hline HI-Other & КТМ009 & 4 & 2003 & 3 & CBD & - & Yes & No & Yes & Yes & N/A \\
\hline HI-Other & JND002 & 3 & 2005 & 4 & Male & - & Yes & No & Yes & Yes & N/A \\
\hline
\end{tabular}

(mean condition code $=3.05, \mathrm{SD}=0.66)$ than those during non-UME years $(P=0.02)$ or $2005(P=0.07)$ (Figure 3$)$. Live strandings (Code 1$)$ were rare $(n=14)$, occurring during only 7 of the 14 years in the time series and with not more than two in any non-UME year; 10 died (naturally or euthanized), 2 were released immediately, and 2 were released after rehabilitation. Whereas no live strandings were found in 1999, five occurred during 2005. Two of the live strandings in 2005 were recovered in estuarine waters, representing the only porpoise strandings recovered inshore during 1997-2009. The first inshore stranding occurred on 18 March when a harbor porpoise found swimming in a drainage canal was removed, roto tagged, and transported to ocean waters where it was released. The second occurred on 8 May in northern Currituck Sound and was euthanized. Subsequently, both animals tested positive for Bartonella infection [10]. The three other live strandings in 2005 were in poor condition and euthanized, one after sustaining serious injuries from being pecked by gulls (Larus sp.).

Human interactions could not be determined (HI-CBD) for most carcasses during non-UME years (75\%), 2005 (81\%), or 1999 (81\%) (Figure 3). The relative frequency of carcasses assigned to the four HI categories (HI-FI, HI-Other, HI-No, and HI-CBD) was similar between non-UME years and 2005 $(P=0.33)$ and $1999(P=0.46)$ as well as between 2005 and $1999(P=1.00)$. The relative frequency was also similar for carcasses when a human interaction could be determined, that is, when HI-CBD was excluded (non-UME years v. 2005, $P=0.17$; v. $1999, P=0.44 ; 2005$ v. $1999, P=1.00)$. Although sample size was small, almost twice the rate of carcasses were HI during UME years (50\% in 2005, 45\% in 1999) than those during non-UME years (26\%). In all years, entanglement lesions were the most common form of HI evidence $(n=11)$, and one of those carcasses also had a slit along the abdomen and the dorsal fin was cut off (Table 1). All strandings categorized as HI-Other had similar mutilations, but decomposition, scavenger damage, or both prevented the determination of whether entanglement lesions were present or absent (Table 1). One of the HI-FI animals had a penetrating wound near the blowhole that might have been from a fishing gaff.

3.3. Pathology Findings from 2005 Strandings. Of the 42 carcasses recovered (one animal was released alive), few were of sufficient quality to assess gross pathology and fewer still were suitable for histologic assessment. Over half $(n=27)$ of all carcasses sustained moderate to heavy scavenger damage (e.g., from gulls and foxes), often leaving no internal organs to examine or sample. Emaciation could be determined for only 17 carcasses and, of these, 9 were emaciated. There was no difference in the relative number of emaciated animals between non-UME years (60\% emaciated) and $2005(50 \%$ emaciated) $(P=0.58)$ or $1999(76 \%$ emaciated $)(P=0.12)$ and a marginal difference between 1999 and $2005(P=0.07)$. During 2005, an assessment of whether there were stomach 


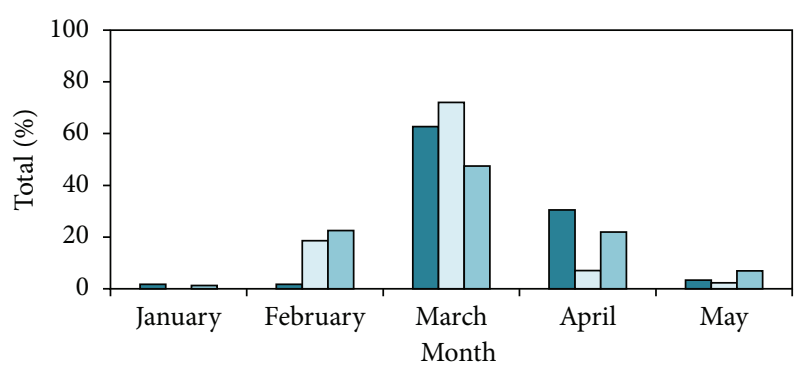

(a)

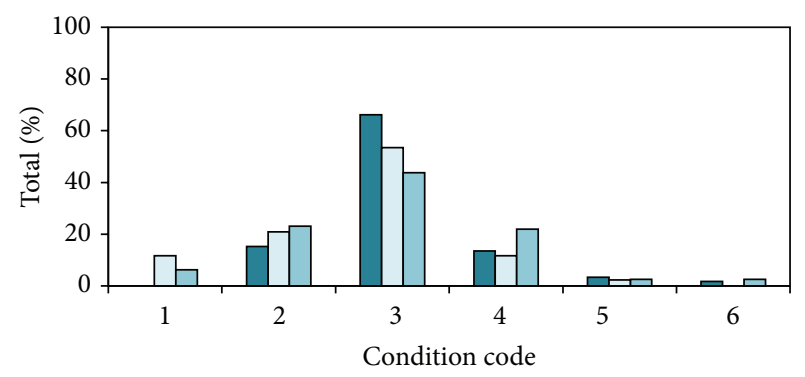

(b)

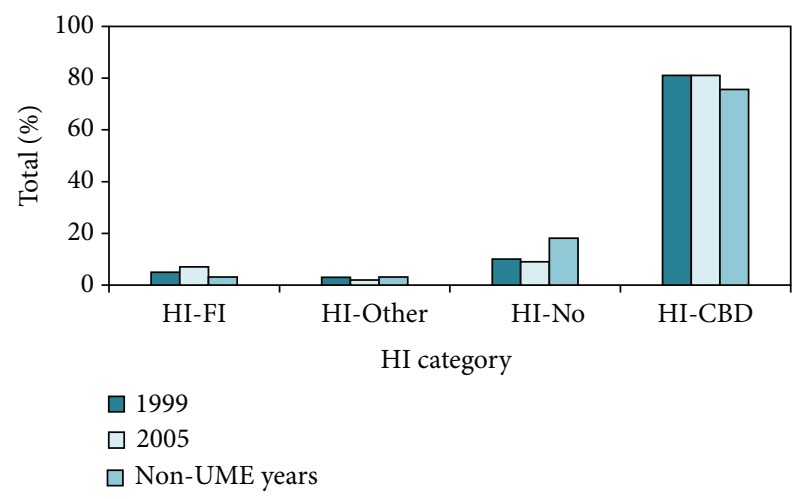

(c)

FIGURE 3: Harbor porpoise strandings by month (a), condition code (b), and human interaction (HI) category (c) as a percentage of the total for $1999(n=59), 2005(n=43)$, and non-UME years ( $n=160)$. Condition codes are (1) live animal, (2) carcass-fresh dead, (3) carcass-moderately decomposed, (4) carcass-advanced decomposition, (5) carcass-mummified or skeletal remains, and (6) disposition unknown. HI categories are HI-FI (evidence of Fishery Interaction), HI-Other (other evidence of HI), HI-No (no evidence of $\mathrm{HI}$ ), and HI-CBD (HI could not be determined).

contents was possible only for 21 strandings (13 empty: 10 $\mathrm{HI}-\mathrm{CBD}, 2 \mathrm{HI}-\mathrm{FI}$, and $1 \mathrm{HI}-\mathrm{No}$; 8 with contents: $7 \mathrm{HI}-\mathrm{CBD}$ and 1 HI-No). Five porpoises had evidence of interspecific aggression; however, the presence/absence of evidence could not be determined for 31 porpoises. Limited necropsies were conducted for 14 carcasses, and only external exams were conducted for 23. Of the limited necropsies, five animals (all HI-CBD) had varying amounts of tracheal froth suggesting an agonal response consistent with live stranding or gear entanglement [37].

Six (14\%) animals received complete necropsies and histopathologic assessment. Three of these six animals were emaciated. Gross lesions were observed in four systems: sensory, respiratory, integumentary, and hepatobiliary (Table 2). Overall, the integumentary and respiratory systems accounted for the greatest percentage of gross lesions, including scavenger lesions $(3 / 6,50 \%)$, entanglement lesions $(2 / 6,33 \%)$, a penetrating wound near the blowhole $(1 / 6,16 \%)$, fresh rake marks $(1 / 6,16 \%)$, adherent material to the fluke $(1 / 6,16 \%)$, verminous pneumonia $(1 / 6,16 \%)$, and pulmonary edema $(1 / 6,16 \%)$. In the hepatobiliary and sensory system, there were focal biliary hyperplasia $(1 / 6,16 \%)$ and pooled blood in the ears $(1 / 6,16 \%)$. All but one animal had stomach compartments devoid of contents.

Histologic lesions involved the respiratory $(3 / 6,50 \%)$, integumentary $(2 / 6,33 \%)$, hepatobiliary $(3 / 6,50 \%)$, hematopoietic/lymphoreticular $(3 / 6,50 \%)$, digestive $(3 / 6,50 \%)$, sensory $(2 / 6,33 \%)$, and nervous systems $(1 / 6,16 \%)$ (Table 3$)$. The lesions ranged from incidental (no effect on the animal) to significant (some effect on the animal). There was no commonality of lesions. Endoparasitism was a common finding in the liver (hepatobiliary) $(3 / 6,50 \%)$ and lung (respiratory system) $(3 / 6,50 \%)$. Parasites, including nematodes in the lung (Figure 6) and trematode ova in the liver (Figure 7), were not always evident in the lesions; however, the presence of eosinophils and granulomatous inflammation were supportive of their presence. In addition to inflammation in the liver, there were biliary hyperplasia (increased number of bile ducts) and fibrosis of the portal tracts. The changes in the lung and liver denoted chronic inflammation. A single emaciated porpoise had lesions suggestive of septicemia including splenic necrosis and lymphoid depletion; however, bacteria were not observed. Other findings for this animal included superficial algal dermatitis (Figure 8) and pancreatic atrophy.

Other lesions observed were incidental. The animal with a penetrating wound had inflammation of the adipose of the site of puncture (steatitis); however, there was no evidence of systemic infection related to this wound. Perimortem hypoxic changes including myelin sheath swelling in the brain were observed in one porpoise and mild retinal atrophy and corneal edema in another, with the latter likely resulting from superficial trauma perhaps at the time of stranding. Two porpoises had mild eosinophilic inflammation in the small and large intestine that may have been associated with parasitic infection. Lymph nodes in two animals were reactive with one lymph node containing eosinophils in increased numbers. While a cause of this was not evident, it does indicate antigenic stimulation.

\section{Discussion}

Both 2005 (the declared UME) and 1999 (an undeclared UME) sustained stranding levels that exceeded the UME threshold indicators for a marked increase in strandings for harbor porpoises in NC. Using the threshold criteria, and because stranding frequency in 1999 was higher than in that 2005, there is justification for considering 1999 as a UME year for harbor porpoises. The characteristics of porpoise strandings in NC remained similar throughout the years except for shifts in timing of strandings between UME and non-UME years, albeit all were within the normal timeframe. 
TABLE 2: Specific gross necropsy findings by system for the six harbor porpoises with submitted tissues for histopathologic evaluation. Each porpoise is listed by its field identification number. Cells for human interaction (HI) evidence are listed as follows: HI-FI (evidence of fishery interaction), HI-No (no evidence of HI), and HI-CBD (could not be determined).

\begin{tabular}{|c|c|c|c|c|c|c|}
\hline System affected & JND003 & KMS387 & KMS389 & KMS404 & KMS417 & MLC001 \\
\hline Body-general & - & - & Emaciation & - & Emaciation & Emaciation \\
\hline Cardiovascular & - & - & - & - & - & - \\
\hline Digestive & - & - & - & - & - & - \\
\hline Endocrine & - & - & - & - & - & - \\
\hline Hemato/lymphoreticular & - & - & - & - & - & - \\
\hline Hepatobiliary & - & - & - & - & $\begin{array}{l}\text { Focal biliary } \\
\text { hyperplasia }\end{array}$ & - \\
\hline \multicolumn{7}{|l|}{ Integumentary } \\
\hline Scavenger damage & Yes & Yes & Yes & Yes & & \\
\hline HI evidence & HI-CBD & HI-CBD & HI-CBD & HI-FI & HI-FI & HI-No \\
\hline Interspecific aggression evidence & CBD & CBD & No & $\mathrm{CBD}$ & Yes & No \\
\hline Other & - & - & $\begin{array}{l}\text { Adherent } \\
\text { material on } \\
\text { fluke }\end{array}$ & - & $\begin{array}{c}\text { Penetrating } \\
\text { wound near } \\
\text { blowhole }\end{array}$ & - \\
\hline Musculoskeletal & - & - & - & - & - & - \\
\hline Nervous & - & - & - & - & - & - \\
\hline Reproductive & - & - & - & - & - & - \\
\hline Respiratory & $\begin{array}{l}\text { Pulmonary } \\
\text { edema }\end{array}$ & - & $\begin{array}{l}\text { Verminous } \\
\text { pneumonia }\end{array}$ & - & - & - \\
\hline Sensory & - & - & - & - & $\begin{array}{l}\text { Ears-pooled } \\
\text { blood }\end{array}$ & \\
\hline Stomach contents & Full & Empty & Empty & Empty & Empty & Empty \\
\hline Urinary & - & - & - & - & - & - \\
\hline
\end{tabular}

In addition, during UME years twice as many carcasses had signs of HI when it was possible to determine whether an interaction occurred (HI-FI, HI-Other, and HI-No only), while there was an increase in HI-CBD strandings. While this finding was not statistically significant, the proportions of HIFI during UME years were similar to the $63 \%$ of carcasses with entanglement lesions documented in the mid-Atlantic from 1994 to 1996 [25]. Although the preponderance of HI-CBD may negatively bias the number of strandings known to be $\mathrm{HI}$, no correction factor could be applied to each year to adjust for the CBD designations. Nonetheless, bycaught porpoises generally are in good or moderate nutritional condition or not emaciated $[22,25,38]$, while in 2005 half of the carcasses were emaciated.

No cause of the 2005 event in NC was found from gross and histologic findings, possibly due to the low number of specimens examined for pathology. Nonetheless, necropsy and histopathology findings did not differ significantly from other published reports from harbor porpoises, including parasite infestation (e.g., $[11,12,22,39])$. While these parasites may have some effect upon these animals, it is unlikely they caused the strandings. One porpoise had lesions suggestive of possible septicemia based on lymph node depletion and splenic necrosis. However, there was no evidence of inflammation in other organs or bacteria in the lesions. Some types of organ lesions were considered mild or incidental without a net effect upon the animal. In contrast, other findings, such as zymogen granule depletion in the pancreas, are indicators of the overall body condition (e.g., emaciation). Of the three emaciated specimens, zymogen granule depletion was observed in a single porpoise. Some animals may have had disease processes that were not determined due to poor carcass condition and histologically nondiagnostic samples. Nonetheless, in the animals examined, no overwhelming systemic disease or infection was found. Therefore, if the six examined animals represent a true cross-section of the stranded population, the cause of strandings is unlikely to be infectious in nature. Although gross findings from the 2005 strandings provide the first indication of interspecific aggression in NC, the rate was low suggesting it was not a primary cause of the UME.

Diagnostic testing for Bartonella infection was previously reported for the live harbor porpoises found in the estuary in $2005[9,10]$. In addition to these porpoises, Bartonella infection was found in other stranded cetaceans [10] and loggerhead sea turtles (Caretta caretta) from NC [40]. Maggi et al. [9] suggested that "bartonellosis may become an important emerging marine mammal infectious disease." However, the extent of Bartonella infection among marine mammal populations and its results are not known because (1) stranded specimens are not routinely tested, (2) subtle effects of Bartonella prevent analysis of suspected cases, and (3) Bartonella 
TABLE 3: Specific histologic findings by system for the six harbor porpoises for which tissues were submitted for histopathologic evaluation. Each porpoise is listed by its field identification number.

\begin{tabular}{|c|c|c|c|c|c|c|}
\hline System affected & JND003 & KMS387 & KMS389 & KMS404 & KMS417 & MLC001 \\
\hline Body-general & - & - & - & - & - & - \\
\hline Cardiovascular & - & - & - & - & - & - \\
\hline Digestive & - & $\begin{array}{c}\text { Mucosal } \\
\text { hyperplasia }\end{array}$ & $\begin{array}{l}\text { (1) Pancreas-zymogen } \\
\text { granule depletion, } \\
\text { (2) Colitis }\end{array}$ & - & - & $\begin{array}{c}\text { Eosinophilic } \\
\text { enteritis }\end{array}$ \\
\hline Endocrine & - & - & - & - & - & - \\
\hline Hemato/lymphoreticular & - & $\begin{array}{l}\text { Reactive lymph } \\
\text { node }\end{array}$ & $\begin{array}{l}\text { (1) Spleen-necrosis, } \\
\text { (2) Lymph node } \\
\text { depletion }\end{array}$ & - & - & $\begin{array}{l}\text { (1) Hyperplasia, } \\
\text { (2) Eosinophilia }\end{array}$ \\
\hline Hepatobiliary & $\begin{array}{l}\text { (1) Bile duct } \\
\text { hyperplasia, } \\
\text { (2) Pericholangitis }\end{array}$ & - & - & $\begin{array}{c}\text { Biliary } \\
\text { hyperplasia }\end{array}$ & $\begin{array}{l}\text { Hepatic } \\
\text { trematodiasis }\end{array}$ & - \\
\hline Integumentary & - & - & Algal dermatitis & - & Steatitis & - \\
\hline Musculoskeletal & - & - & - & - & - & - \\
\hline Nervous & - & - & - & - & $\begin{array}{l}\text { Myelin sheath } \\
\text { swelling }\end{array}$ & - \\
\hline Reproductive & - & - & - & - & - & - \\
\hline Respiratory & - & $\begin{array}{l}\text { Eosinophilic } \\
\text { broncho- } \\
\text { pneumonia }\end{array}$ & $\begin{array}{l}\text { Verminous } \\
\text { pneumonia }\end{array}$ & - & - & $\begin{array}{l}\text { Eosinophilic } \\
\text { interstitial } \\
\text { pneumonia }\end{array}$ \\
\hline Sensory & - & - & - & - & $\begin{array}{l}\text { (1) Corneal } \\
\text { edema, } \\
\text { (2) Retinal } \\
\text { atrophy }\end{array}$ & - \\
\hline Urinary & - & - & - & - & - & - \\
\hline
\end{tabular}

can be difficult to detect [10]. In addition, marine mammals may be asymptomatic carriers similar to domestic and freeranging terrestrial felids [41, 42]. It is unlikely, however, that Bartonella infection was responsible for the UME in 2005 based on the lack of histologic findings, such as uveitis and myocarditis, observed in other species.

The majority of harbor porpoise strandings in NC, during UME and non-UME years, are young-of-year (YOY). Harbor porpoises are synchronized, seasonal breeders [43, 44]. In the western North Atlantic, most females calve annually with peak parturition in May [36]. Lactation duration is mostly speculative, but it appears to be eight to 12 months [43]. Given the month of stranding and body length (predicted length at $1 \mathrm{yr}=118 \mathrm{~cm},[35])$, most of these YOYs are approximately the size at weaning, and they would be 9-11 months of age. Porpoise strandings in Maryland, Virginia, and NC during 1994-1996 were also predominantly YOY [25]. YOY may be more common in the stranding record because they have a higher mortality rate [43]. For example, as newly weaned animals they are likely to be novice foragers, and even though juveniles have some of the thickest blubber [35], weight loss can be dramatic for porpoises not feeding [45]. For an animal with such important thermoregulatory needs and given that most were newly weaned, emaciation would be extremely deleterious due to physiologic stress associated with inadequate protection from cold water and lack of nutrients, including electrolytes and calories. Of the animals in 2005 that could be categorized as emaciated or robust, almost half were emaciated. Whether the emaciation was the primary cause of death, possibly resulting from recently weaned individuals being unable to forage on their own, or a secondary effect of undetected pathologies is unknown.

Spatial segregation may also contribute to the prevalence of YOY strandings. Cox et al. [25] found that the mean length of HI-FI stranded porpoises along the mid-Atlantic coast of the USA was significantly smaller than that of porpoises documented as bycatch by fishery observers. Because most of the bycaught animals were entangled far from shore, they concluded that spatial segregation occurs between mature and immature animals resulting in a decreased likelihood of mature animals stranding. In addition, immature porpoises from the North Sea to the western Baltic Sea have been shown to have larger ranges than mature animals [46]. Thus, if YOYs are closer to shore, they likely would be more represented in the stranding record.

Elevated strandings of harbor porpoises have been reported elsewhere. Notably, in a study of 55 stranded porpoises from 1990 to 2000, the number of strandings increased multifold along the Belgium and northern France coasts during 1999 [47]. The primary findings included emaciation (60\%), bronchopneumonia (49\%), and parasitosis (51\%), while $70 \%$ had empty stomachs. Only $15 \%$ were attributed to bycatch. The authors suggested that the increase in strandings may have been due to an increase in the number of porpoises in the southern North Sea, possibly due to a shift in distribution during the latter years of the study 

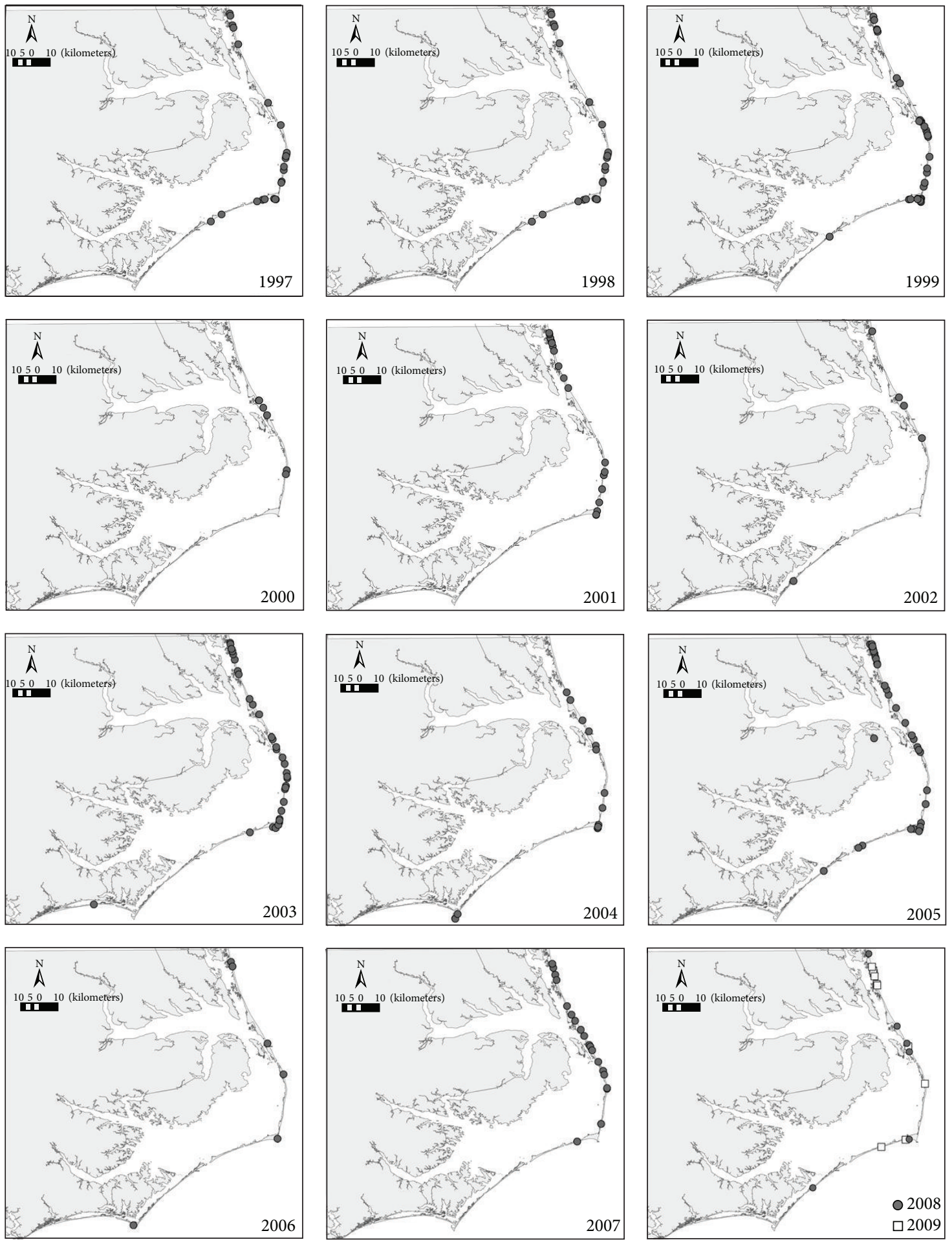

FIGURE 4: Annual harbor porpoise strandings in North Carolina, 1997-2009. In addition, in 2009 one stranding was recovered in Topsail Beach (see Figure 1).

and particularly in 1999, because the number of strandings in the nearby English Channel had also increased during this time. Along the nearby coasts of the Netherlands, porpoise strandings increased from the late 1990s through 2007, also presumably due to migration of primarily juvenile porpoises into the southern North Sea, with some possible contribution from inconsistent strandingresponse effort over time [48]. A particularly notable increase in 2006 was not addressed. Large fluctuations within a small part of the range of harbor porpoises have been 


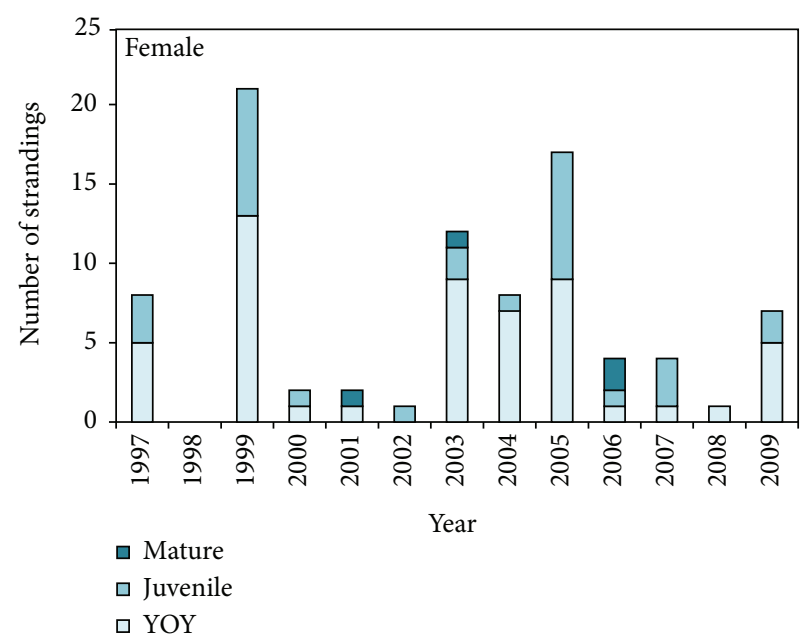

(a)

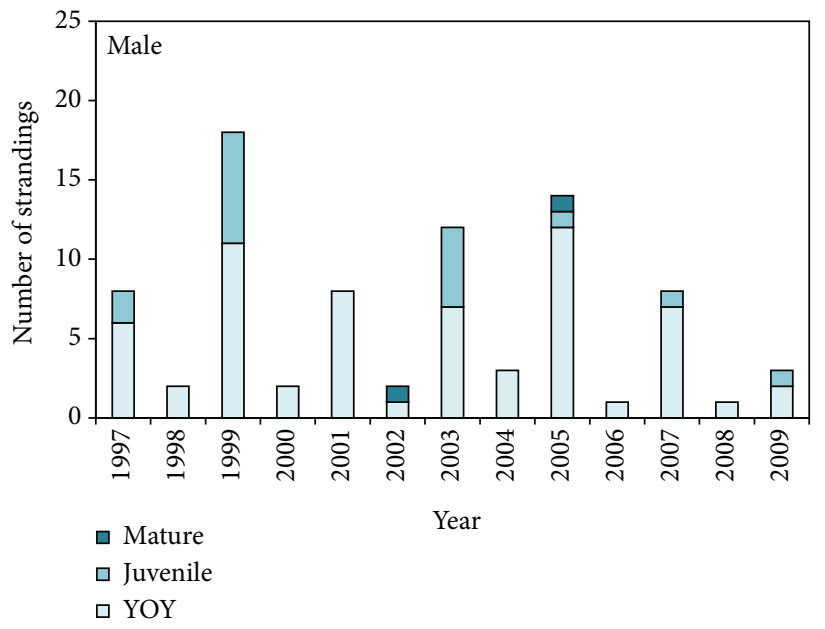

(b)

Figure 5: Age class categories by sex (female $=87$; male $=82$ ) of harbor porpoise strandings in North Carolina during 1997-2009: Youngof-Year (YOY) $(\leq 118 \mathrm{~cm}$ ); juvenile (females $=119-142 \mathrm{~cm}$; males $=119-134 \mathrm{~cm})$; mature (females $\geq 143 \mathrm{~cm}$; males $\geq 135 \mathrm{~cm}$ ). Strandings of unknown sex or for which lengths were estimated were excluded.

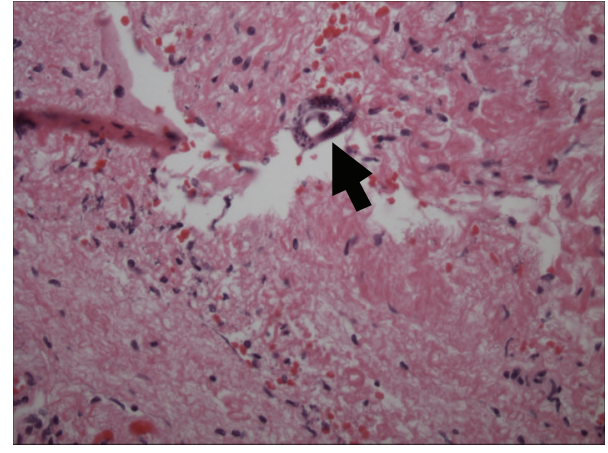

FIGURE 6: Microscopic section of lung from KMS389. Nematode larvae are present within regions of parenchymal destruction and fibrosis.

reported off the coast of Scotland [49], so local increases in abundance combined with similar stranding rates could result in a multifold increase in frequency of strandings. An increase in Danish strandings during a 9-day period in 2005 was declared a UME [24]. The incidence of potentially bycatch-related injuries during this event was higher than that in non-UME years 2003-2008, and the presence of naval activity correlated in models with higher rates of strandings. In 2007, a mass mortality of harbor porpoises and harbor seals (Phoca vitulina) was reported during a 2-month period along the Swedish coast [50]. The cause appeared to be an unknown pathogenic virus. Elevated strandings of harbor porpoises caused primarily by aggressive interactions with bottlenose dolphins occurred along the central coast of California from 2007-2009 [18]. Thus, the cause of unusually high stranding frequencies can be caused by various unrelated factors and the cause of harbor porpoise unusual stranding events in the western Atlantic and Belgium/northern France in 1999 [47] or the Danish coast in 2005 [24] seems unrelated.

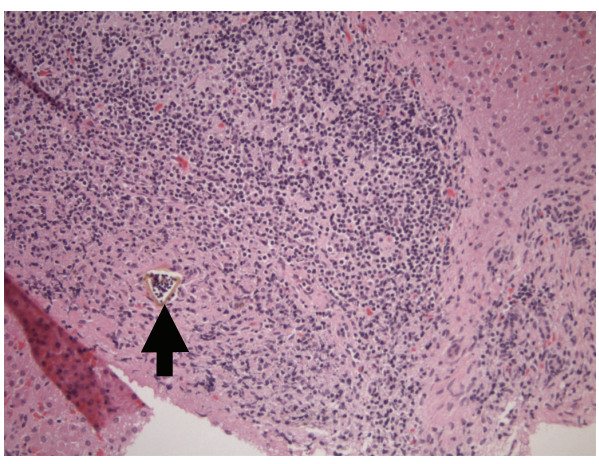

FIGURE 7: Section of the liver from KMS417. Trematode ova are present within the portal tract surrounded by mixed inflammatory cells.

The events have in common high rates of emaciation and empty stomachs as well as parasitosis, a common finding in stranded harbor porpoises (e.g., [11, 22]), but not an infectious disease. In addition, harbor porpoises in the eastern and western Atlantic comprise separate stocks and little, if any, mixing occurs [51].

The use of a quantitative approach, such as developing a threshold, to define a marked increase in the magnitude of strandings relative to historic levels provides a relatively objective and straightforward means of evaluating whether an event is occurring or occurred and how elevated stranding numbers are compared among years. When strandings occur year-round, such as for harbor porpoises in California, seasonal adjustments can remove variability that may obscure true unusual seasonal increases in strandings [18]. Detection of anomalies in stranding patterns may be enhanced by including the influence of carcass drift [52]. These methods have in common use of a quantitative, objective means to compare potentially elevated numbers to average stranding 


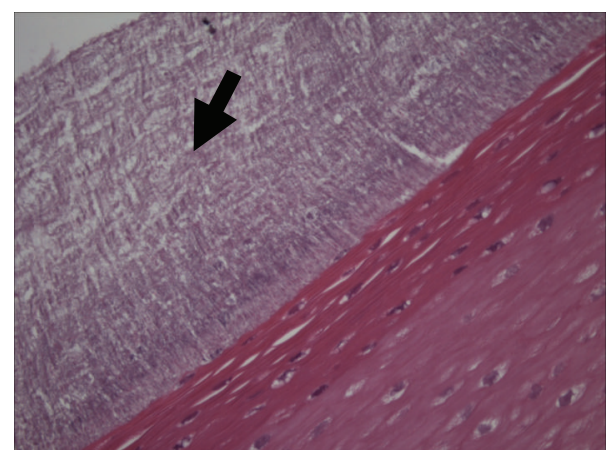

FIGURE 8: Algae adhered to the superficial epithelium of KMS 389. Algae are arranged in dense sheets.

patterns. Reevaluating UMEs in light of additional timeseries data can confirm UMEs or, possibly, help determine if a gradual increase or decrease in number of strandings is resulting in a shifting threshold.

A UME indicator is needed in real time to ascertain that an event is occurring. In the USA, formal declaration of a UME provides opportunity to request/obtain support for enhanced response and beneficial oversight to ensure standardized sampling and testing [32]. For harbor porpoises in $\mathrm{NC}$, weekly assessment is an appropriate metric because the stranding season is relatively contracted, and strandings are sufficiently infrequent in many years that a finer-scale time frame could not be supported. For other situations, more or less frequent comparisons may be appropriate, including biweekly [53], monthly [54], seasonally [18, 34, 52], or annually [55]. Retrospective examination of annual stranding numbers may provide a different perspective, such as the current finding that harbor porpoise strandings in 2003 exceed the annual stranding threshold and, thus, potentially could have been a UME. Such retrospective information will not help with current stranding response, including implementing specific protocols adopted for an UME, but may assist with detecting future UMEs by influencing which years are included for calculating the threshold. This approach also assists with interpreting historical stranding data. For example, from 1975 to 1989, harbor porpoises were reported stranding in NC in low numbers except for the spring of 1977 when 60 porpoise strandings were documented [4]. It is possible that the reported numbers across those years underestimated the true number of strandings because a comprehensive stranding network was not yet developed, but in 1977 the reported level would have exceeded the thresholds developed in recent years when stranding reports were more systematic and reliable.

In NC, the harbor porpoise is a challenging species for robust stranding response because, per our long-term observations, more than most dolphins or whales these small carcasses can be difficult to detect on beaches, wash out at high tides fairly easily, are consumed quickly by gulls and other predators, and decompose rapidly, even during winter. Almost certainly, the number of porpoises detected is negatively biased. A more robust response for this species would have required stationing teams of responders along the $160 \mathrm{~km}$ of coast where the majority of porpoise strand. However, when UMEs occur over short periods, there frequently is insufficient time to implement this type of increased response. As a result, it is often possible to determine that an unusually high number of porpoises are stranded without obtaining sufficient information from those strandings to determine the cause of the event.

4.1. Conclusions. Harbor porpoises strand annually along NC beaches in highly variable numbers. Periodically, increases in the frequency of standings result in Unusual Mortality Events. The cause of the most recent UME, in 2005, could not be determined. Relative to non-UME years and to an undeclared UME during 1999, there were no significant differences in age class, sex ratio, or spatial distribution of strandings and only a suggestion of an increase in fishery interactions. There was a significant temporal effect, with a peak in strandings during one month rather than more distributed over 3 months; however, they occurred within the normal timeframe of porpoise strandings. No overall cause of the 2005 event in NC was found from gross and histologic findings and, except for parasite infestation typical for harbor porpoises, there was no commonality in findings and no pervasive evidence of infectious disease. Potential unexplored explanatory factors include an increase in mortality rate due to an unidentified cause, such as reduced prey availability, an increase in strandings due to changes in abundance or distribution off the NC coast, or a shift in environmental conditions such as wind [56-58]. Response to harbor porpoise UMEs is especially challenging, particularly along the vast expanses of NC beaches, requiring additional effort to obtain carcasses in sufficient condition to determine the cause of these events.

\section{Acknowledgments}

The authors are grateful for the dedicated participants in the NC Marine Mammal Stranding Network. During the 2005 UME response, the authors especially thank Karen S. Altman, Mary Burkart, Jaclyn Daly, Mark Grossman, Craig Harms, Gary Henson, Emma Jugovich, Gretchen Lovewell, Robert MacLean, Jackie Orsulak, and Wendy Walton. During the remaining years, the authors want to also acknowledge Michelle Bogardus, Karen Clark, Bruce Ferrier, Patrick Martone, Kathleen Moore, and resident veterinarians at the College of Veterinary Medicine, North Carolina State University. The authors offer their gratitude to the staff of the U.S. Fish and Wildlife Service, Alligator National Wildlife Refuge, and the USA Coast Guard Oregon Inlet for their support in the rescue and release of stranding AAH009, and to the Virginia Aquarium Stranding Response Program and the Riverhead Foundation for Marine Research and Preservation for their work rehabilitating live porpoises. Larisa Avens and Michael Moore provided thoughtful comments on the paper.

\section{References}

[1] A. Bjorge and K. Tolley, "Harbor porpoise (Phocoena phocoena)," in Encyclopedia of Marine Mammals, W. F. Perrin, B. 
Würsig, and J. G. M. Thewissen, Eds., pp. 549-552, Academic Press, San Diego, Calif, USA, 2002.

[2] C. D. Orphanides, "Protected species bycatch estimating approaches: estimating harbor porpoise bycatch in U.S. northwestern Atlantic gillnet fisheries," Journal of Northwest Atlantic Fishery Science, vol. 42, pp. 55-76, 2009.

[3] B. L. Byrd, A. A. Hohn, G. N. Lovewell et al., "Strandings illustrate marine mammal biodiversity and human impacts off the coast of North Carolina, USA," Fishery Bulletin. In review.

[4] T. Polacheck, F. W. Wenzel, and G. Early, "What do stranding data say about harbor porpoises (Phocoena phocoena)?" Report of the International Whaling Commission Special Issue, vol. 16, pp. 169-179, 1995.

[5] S. Kennedy, I. J. Lindstedt, M. M. Mcaliskey, S. A. Mcconnell, and S. J. Mccullough, "Herpesviral encephalitis in a harbor porpoise (Phocoena phocoena)," Journal of Zoo and Wildlife Medicine, vol. 23, pp. 374-379, 1992.

[6] A. Wunschmann, U. Siebert, K. Frese et al., "Evidence of infectious diseases in harbour porpoises (Phocoena phocoena) hunted in the waters of Greenland and by-caught in the German North Sea and Baltic Sea," Veterinary Record, vol. 148, no. 23, pp. 715-720, 2001.

[7] T. P. Jauniaux, C. Brenez, D. Fretin et al., "Brucella ceti infection in harbor porpoise (Phocoena phocoena)," Emerging Infectious Diseases, vol. 16, no. 12, pp. 1966-1968, 2010.

[8] S. Sears, K. Colby, R. Tiller, M. Guerra, J. Gibbins, and M. Lehman, "Human exposures to marine Brucella isolated from a harbor porpoise-Maine, 2012," Morbidity and Mortality Weekly Report, vol. 61, no. 25, pp. 461-463, 2012.

[9] R. G. Maggi, C. A. Harms, A. A. Hohn et al., "Bartonella henselae in porpoise blood," Emerging Infectious Diseases, vol. 11, no. 12, pp. 1894-1898, 2005.

[10] C. A. Harms, R. G. Maggi, E. B. Breitschwerdt et al., "Bartonella species detection in captive, stranded and free-ranging cetaceans," Veterinary Research, vol. 39, no. 6, article 59, 2008.

[11] P. D. Jepson, J. R. Baker, T. Kuiken, V. R. Simpson, S. Kennedy, and P. M. Bennett, "Pulmonary pathology of harbour porpoises (Phocoena phocoena) stranded in England and Wales between 1990 and 1996," Veterinary Record, vol. 146, no. 25, pp. 721-728, 2000.

[12] U. Siebert, A. Wünschmann, R. Weiss, H. Frank, H. Benke, and K. Frese, "Post-mortem findings in harbour porpoises (Phocoena phocoena) from the German North and Baltic Seas," Journal of Comparative Pathology, vol. 124, no. 2-3, pp. 102-114, 2001.

[13] J. R. Geraci, N. C. Palmer, and D. J. St. Aubin, "Tumors in cetaceans: analysis and new findings," Canadian Journal of Fisheries and Aquatic Sciences, vol. 44, pp. 1289-1300, 1987.

[14] M.-F. Van Bressem, R. A. Kastelein, P. Flamant, and G. Orth, "Cutaneous papillomavirus infection in a harbour porpoise (Phocoena phocoena) from the North Sea," Veterinary Record, vol. 144, no. 21, pp. 592-593, 1999.

[15] M.-F. van Bressem, K. van Waerebeek, and J. A. Raga, "A review of virus infections of cetaceans and the potential impact of morbilliviruses, poxviruses and papillomaviruses on host population dynamics," Diseases of Aquatic Organisms, vol. 38, no. 1, pp. 53-65, 1999.

[16] U. Schumacher, S. Zahler, H. P. Horny, G. Heidemann, K. Skirnisson, and U. Welsch, "Histological investigations on the thyroid glands of marine mammals (Phoca vitulina, Phocoena phocoena) and the possible implications of marine pollution," Journal of Wildlife Diseases, vol. 29, no. 1, pp. 103-108, 1993.
[17] J. R. Baker and A. R. Martin, "Causes of mortality and parasites and incidental lesions in harbour porpoises (Phocoena phocoena) from British waters," Veterinary Record, vol. 130, no. 25, pp. 554-558, 1992.

[18] S. Wilkin, "An unusual mortality event of harbor porpoises (Phocoena phocoena) off central California: increase in blunt trauma rather than an epizootic," Aquatic Mammals, vol. 38, no. 3, pp. 301-310, 2012.

[19] P. D. Jepson, P. M. Bennett, R. Deaville, C. R. Allchin, J. R. Baker, and R. J. Law, "Relationships between polychlorinated biphenyls and health status in harbor porpoises (Phocoena phocoena) stranded in the United Kingdom," Environmental Toxicology and Chemistry, vol. 24, no. 1, pp. 238-248, 2005.

[20] J. Barlow and D. Hanan, "An assessment of the status of the harbour porpoise in central California," Report of the International Whaling Commission Special Issue, vol. 16, pp. 123-140, 1995.

[21] J. K. Kirkwood, P. M. Bennett, P. D. Jepson, T. Kuiken, V. R. Simpson, and J. R. Baker, "Entanglement in fishing gear and other causes of death in cetaceans stranded on the coasts of England and Wales," Veterinary Record, vol. 141, no. 4, pp. 94-98, 1997.

[22] U. Siebert, A. Gilles, K. Lucke et al., "A decade of harbour porpoise occurrence in German waters-analyses of aerial surveys, incidental sightings and strandings," Journal of Sea Research, vol. 56, no. 1, pp. 65-80, 2006.

[23] R. H. Leeney, R. Amies, A. C. Broderick et al., "Spatio-temporal analysis of cetacean strandings and bycatch in a UK fisheries hotspot," Biodiversity and Conservation, vol. 17, no. 10, pp. 2323$2338,2008$.

[24] A. J. Wright, M. Maar, C. Mohn et al., "Possible causes of a harbour porpoise mass stranding in Danish waters in 2005," PLoS ONE, vol. 8, no. 2, Article ID e55553, 2013.

[25] T. M. Cox, A. J. Read, S. Barco et al., "Documenting the bycatch of harbor porpoises, Phocoena phocoena, in coastal gillnet fisheries from stranded carcasses," Fishery Bulletin, vol. 96, no. 4, pp. 727-734, 1998.

[26] T. Kuiken, V. R. Simpson, C. R. Allchin et al., "Mass mortality of common dolphins (Delphinus delphis) in south west England due to incidental capture in fishing gear," Veterinary Record, vol. 134, no. 4, pp. 81-89, 1994.

[27] A. J. Read and K. T. Murray, "Gross evidence of human-induced mortality in small cetacea," NOAA Technical Memorandum NMFS-OPR-15, U.S. Department of Commerce, Silver Spring, Md, USA, 2000.

[28] M. P. Cotter, D. Maldini, and T. A. Jefferson, "Porpicide' in California: killing of harbor porpoises (Phocoena phocoena) by coastal bottlenose dolphins (Tursiops truncatus)," Marine Mammal Science, vol. 28, no. 1, pp. E1-E15, 2012.

[29] R. W. Baird, "An interaction between Pacific white-sided dolphins and a neonatal harbor porpoise," Mammalia, vol. 62, no. 1, pp. 129-134, 1998.

[30] H. M. Ross and B. Wilson, "Violent interactions between bottlenose dolphins and harbour porpoises," Proceedings of the Royal Society B, vol. 263, no. 1368, pp. 283-286, 1996.

[31] D. M. Wilkinson, "National contingency plan for response to unusual marine mammal mortality events," NOAA Technical Memorandum NMFS-OPR-9, U.S. Department of Commerce, Silver Spring, Md, USA, 1996.

[32] L. A. Dierauf and F. M. D. Gulland, "Marine mammal unusual mortality events," in Marine Mammal Medicine, L. A. Dierauf and F. M. D. Gulland, Eds., pp. 69-79, CRC Press, Boca Raton, Fla, USA, 2nd edition, 2001. 
[33] J. R. Geraci and V. J. Lounsbury, Marine Mammals Ashore: a Field Guide for Strandings, National Aquarium in Baltimore, Baltimore, Md, USA, 2nd edition, 2005.

[34] B. L. Byrd, A. A. Hohn, F. H. Munden, G. N. Lovewell, and R. E. lo Piccolo, "Effects of commercial fishing regulations on stranding rates of bottlenose dolphin (Tursiops truncatus)," Fishery Bulletin, vol. 106, no. 1, pp. 72-81, 2008.

[35] C. Lockyer, "Investigation of aspects of the life history of the harbour porpoise, Phocoena phocoena, in British waters," Report of the International Whaling Commission Special Issue, vol. 16, pp. 189-197, 1995.

[36] A. J. Read and D. E. Gaskin, "Changes in growth and reproduction of harbour porpoises, Phocoena phocoena, from the Bay of Fundy," Canadian Journal of Fisheries and Aquatic Sciences, vol. 47, no. 11, pp. 2158-2163, 1990.

[37] T. P. Lipscomb, "Pathologic findings in dolphins known to have died from underwater entrapment," in Diagnosis of By-Catch in Cetaceans: ProceedIngs of the Second European Cetacean Society Workshop on Cetacean Pathology, T. Kuiken, Ed., pp. 1-3, European Cetacean Society, Montpellier, France, 1994.

[38] C. Lockyer and C. Kinze, "Status, ecology and life history of harbour porpoise (Phocoena phocoena), in Danish waters," NAMMCO Scientific Publications, vol. 5, pp. 143-175, 2003.

[39] S. A. Norman, C. E. Bowlby, M. S. Brancato et al., "Cetacean strandings in Oregon and Washington between 1930 and 2002," Journal of Cetacean Research and Management, vol. 6, no. 1, pp. 87-99, 2004.

[40] K. H. Valentine, C. A. Harms, M. B. Cadenas et al., "Molecular detection of Bartonella DNA in the blood of loggerhead sea turtles (Caretta caretta)," Emerging Infectious Diseases, vol. 13, no. 6, pp. 949-950, 2007.

[41] B. B. Chomel, R. W. Kasten, J. B. Henn, and S. Molia, "Bartonella infection in domestic cats and wild felids," Annals of the New York Academy of Sciences, vol. 1078, pp. 410-415, 2006.

[42] D. S. Rotstein, S. K. Taylor, J. Bradley, and E. B. Breitschwerdt, "Prevalence of Bartonella henselae antibody in Florida panthers," Journal of Wildlife Diseases, vol. 36, no. 1, pp. 157-160, 2000.

[43] C. Lockyer, "Harbour porpoise (Phocoena phocoena) in the north Atlantic: biological parameters," NAMMCO Scientific Publications, vol. 5, pp. 71-90, 2003.

[44] A. J. Read and A. A. Hohn, "Life in the fast lane: the life history of harbor propoises from the Gulf of Maine," Marine Mammal Science, vol. 11, no. 4, pp. 423-440, 1995.

[45] C. Lockyer, G. Desportes, K. Anderson, S. Labberté, and U. Siebert, "Monitoring growth and energy utilisation of the harbour porpoise (Phocoena phocoena) in human care," NAMMCO Scientific Publications, vol. 5, pp. 107-120, 2003.

[46] S. Sveegaard, J. Teilmann, J. Tougaard et al., "High-density areas for harbor porpoises (Phocoena phocoena) identified by satellite tracking," Marine Mammal Science, vol. 27, no. 1, pp. 230-246, 2011.

[47] T. Jauniaux, D. Petitjean, C. Brenez et al., "Post-mortem findings and causes of death of harbour porpoises (Phocoena phocoena) stranded from 1990 to 2000 along the coastlines of Belgium and Northern France," Journal of Comparative Pathology, vol. 126, no. 4, pp. 243-253, 2002.

[48] K. Camphuysen, C. Smeenk, M. Addink, H. van Grouw, and O. E. Jansen, "Cetaceans stranded in the Netherlands from 1998 to 2007," Lutra, vol. 51, pp. 87-122, 2008.
[49] F. Marubini, A. Gimona, P. G. H. Evans, P. J. Wright, and G. J. Pierce, "Habitat preferences and interannual variability in occurrence of the harbour porpoise Phocoena phocoena off northwest Scotland," Marine Ecology Progress Series, vol. 381, pp. 297-310, 2009.

[50] T. Harkonen, B. M. Bäcklin, T. Barrett et al., "Mass mortality in harbour seals and harbour porpoises caused by an unknown pathogen," Veterinary Record, vol. 162, no. 17, pp. 555-556, 2008.

[51] P. E. Rosel, S. C. France, J. Y. Wang, and T. D. Kocher, "Genetic structure of harbour porpoise Phocoena phocoena populations in the northwest Atlantic based on mitochondrial and nuclear markers," Molecular Ecology, vol. 8, no. 12, pp. S41-S54, 1999.

[52] H. Peltier, H. J. Baagøe, K. C. J. Camphuysen et al., "The stranding anomaly as population indicator: the case of harbour porpoise Phocoena phocoena in north-western Europe," PLoS ONE, vol. 8, no. 4, Article ID e62180, 2013.

[53] G. T. de la Riva, C. K. Johnson, F. M. D. Gulland et al., "Association of an unusual marine mammal mortality event with pseudo-nitzschia SPP. Blooms along the southern California coastline," Journal of Wildlife Diseases, vol. 45, no. 1, pp. 109-121, 2009.

[54] S. E. Fire, Z. Wang, M. Byrd, H. R. Whitehead, J. Paternoster, and S. L. Morton, "Co-occurrence of multiple classes of harmful algal toxins in bottlenose dolphins (Tursiops truncatus) stranding during an unusual mortality event in Texas, USA," Harmful Algae, vol. 10, no. 3, pp. 330-336, 2011.

[55] F. M. D. Gulland, H. Pérez-Cortés, R. Urbán et al., “Eastern north Pacific gray whale (Eschrichtius robustus) unusual mortality event, 1999-2000," NOAA Technical Memorandum NMFSAFSC-150, U.S. Department of Commerce, Seattle, Wash, USA, 2005.

[56] S. P. Epperly, J. Braun, A. J. Chester et al., "Beach strandings as an indicator of at-sea mortality of sea turtles," Bulletin of Marine Science, vol. 59, no. 2, pp. 289-297, 1996.

[57] K. M. Hart, P. Mooreside, and L. B. Crowder, "Interpreting the spatio-temporal patterns of sea turtle strandings: going with the flow," Biological Conservation, vol. 129, no. 2, pp. 283-290, 2006.

[58] H. Peltier, W. Dabin, P. Daniel et al., "The significance of stranding data as indicators of cetacean populations at sea: modelling the drift of cetacean carcasses," Ecological Indicators, vol. 18, pp. 278-290, 2012. 

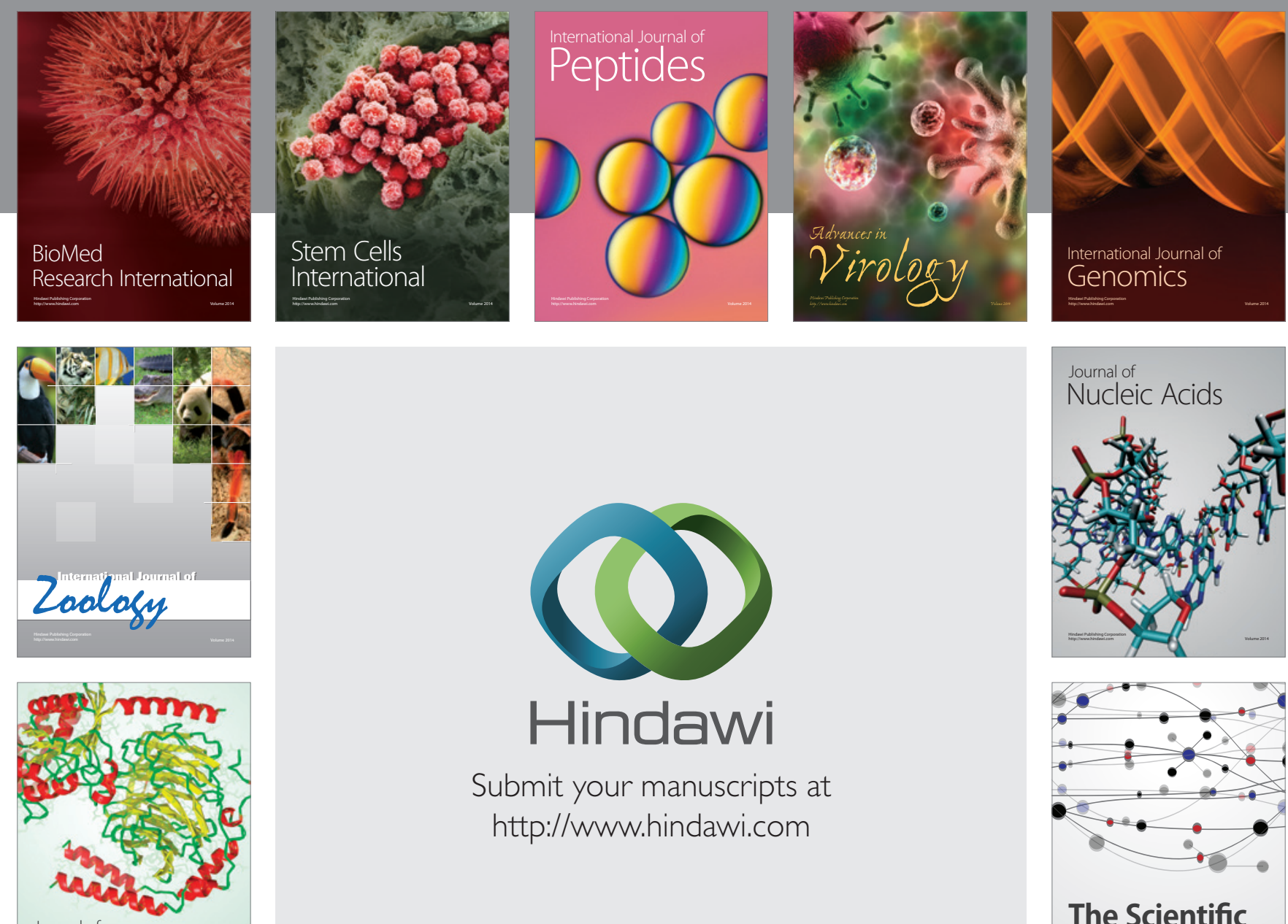

Submit your manuscripts at

http://www.hindawi.com

Journal of
Signal Transduction
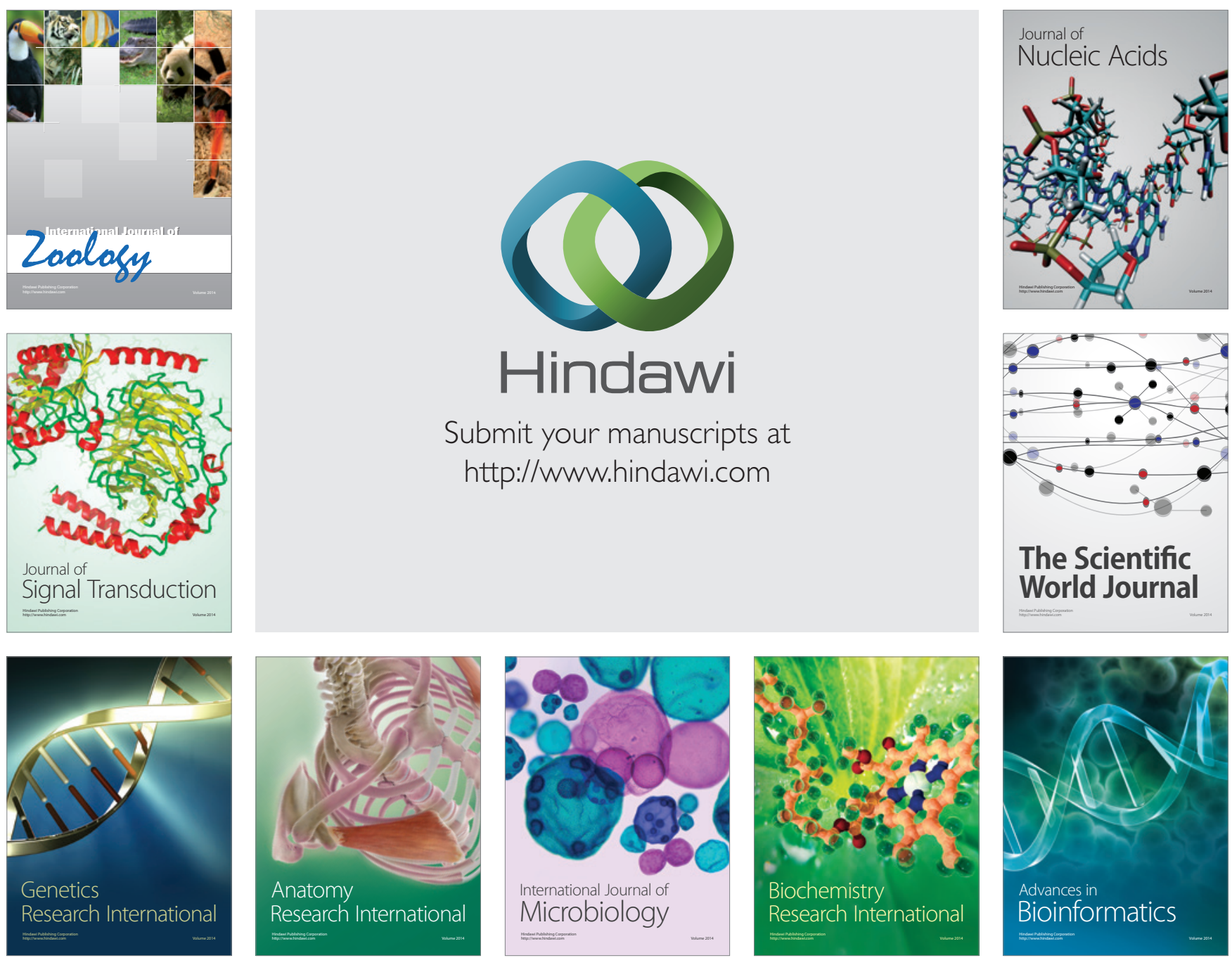

The Scientific World Journal
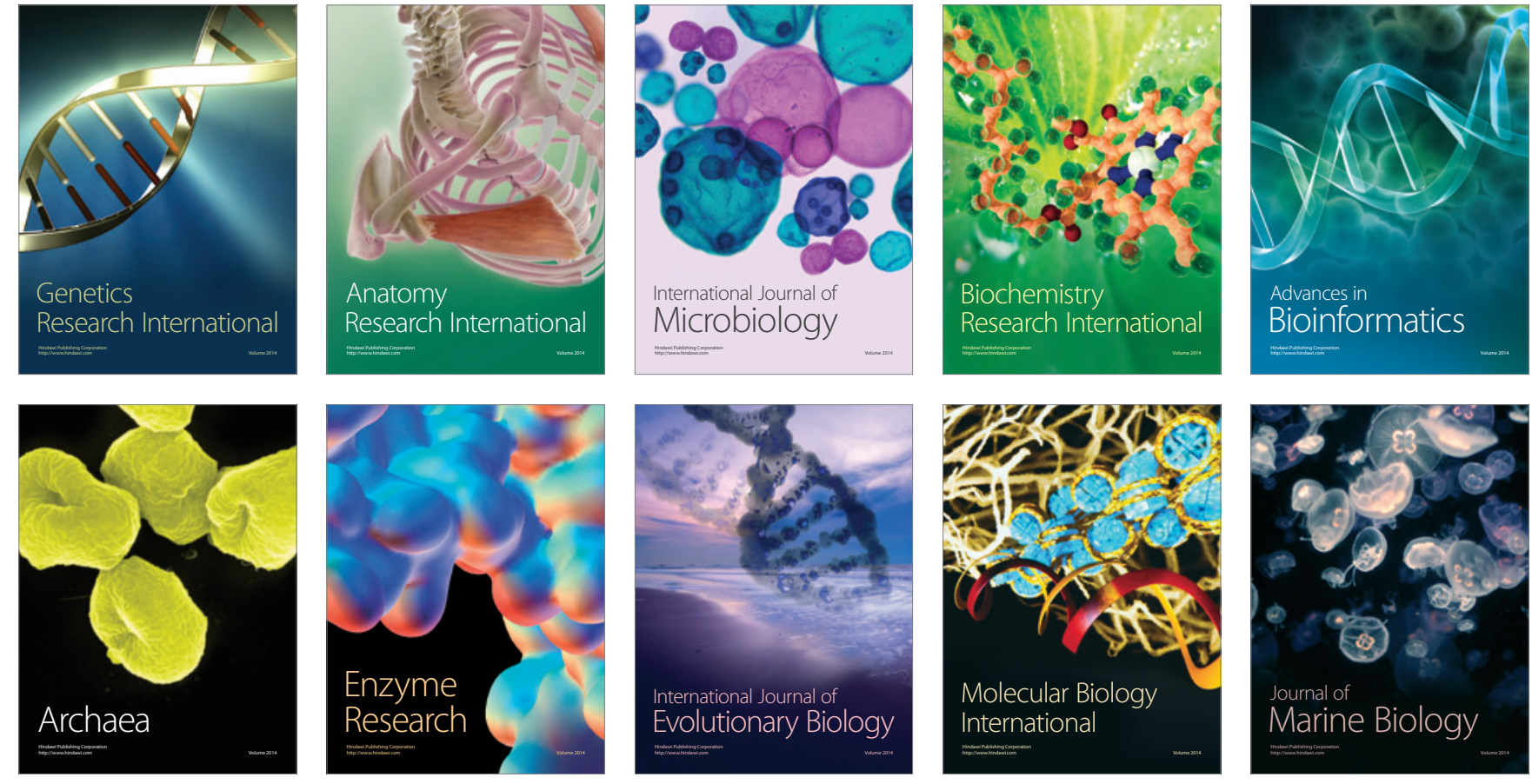